\title{
Evaluasi Pertumbuhan Isolat Probiotik (L. casei dan L. plantarum) dalam Medium Fermentasi Berbasis Ubi Jalar (Ipomoea batatas L.) selama Proses Fermentasi (Kajian Jenis Isolat dan Jenis Tepung Ubi Jalar)
} (Growth Evaluation of Probiotic Isolate (L. casei and L. plantarum) in Fermented Medium Based on Sweet Potato (Ipomoea batatas L.) during Fermentation Process: Study Kind of Isolate and Sweet Potato Flour) Irma Sarita Rahmawati , Elok Zubaida, Ella Saparianti

Teknologi Hasil Pertanian, Fakultas Teknologi Pertanian Universitas Brawijaya, Malang

${ }^{*}$ Korespondensi dengan penulis (irma_sr@ub.ac.id)

Artikel ini dikirim pada tanggal 6 Oktober 2015 dan dinyatakan diterima tanggal 19 November 2015. Artikel ini juga dipublikasi secara online melalui www.jatp.ift.or.id. Hak cipta dilindungi undang-undang. Dilarang diperbanyak untuk tujuan komersial.

Diproduksi oleh Indonesian Food Technologists ${ }^{\circledR} \odot 2015$ (www.ift.or.id)

\begin{abstract}
Abstrak
Ubi Jalar mengandung komponen serat fraksi oligosakarida seperti raffinosa, verbakosa, dan stakhiosa yang berpotensi sebagai prebiotik, yaitu subtrat yang dapat menstimulasi pertumbuhan bakteri probiotik. Tujuan penelitian ini adalah untuk membandingkan viabilitas bakteri probiotik seperti $L$. plantarum dan $L$. casei pada medium fermentasi berbasis tepung ubi jalar dan untuk mengetahui perubahan komponen tepung ubi jalar dari tiga jenis ubijalar selama proses fermentasi. Penelitian ini menggunakan dua faktor: jenis bakteri probiotik ( $L$. casei dan L. plantarum) dan jenis tepung ubi jalar (tepung ubi jalar putih, kuning dan ungu). Data dianalisis dengan ANNOVA dan BNT dengan nilai a $<5 \%$. Perlakuan terbaik dipilih dengan metode Multiple atrribute. Berdasarkan hasil penelitian didapatkan jenis ubi jalar mempengaruhi viabilitas $L$. casei dan $L$. plantarum selama proses fermentasi. Perbedaan jenis tepung ubi jalar secara signifikan berbeda nyata terhadap nilai $\mathrm{pH}$, total asam, total $\mathrm{BAL}$, gula reduksi sedangkan perbedaan jenis bakteri probiotik sangat mempengaruhi nilai $\mathrm{pH}$, total asam, total BAL, total gula, serat kasar, gula reduksi, total nitrogen dan kadar pati. Perbedaan jenis tepung ubi jalar dan bakteri probiotik memiliki perbedaan signifikan (nilai $\mathrm{a}<1 \%$ ) terhadap $\mathrm{pH}$, total asam, total BAL dan gula reduksi. Perlakuan terbaik adalah medium terfermentasi dari tepung ubi jalar ungu $(10 \% \mathrm{~b} / \mathrm{v})$ oleh $\mathrm{L}$. plantarum dengan total BAL yaitu $1,55 \times 10^{10} \mathrm{CFU} / \mathrm{ml}$, total asam $0,953 \%$, nilai $\mathrm{pH} 4,267$ total gula $1,647 \%$, kadar pati $2,567 \%$, serat kasar $0,066 \%$, gula reduksi $3,139 \%$ dan total $\mathrm{N} 0,023 \%$.
\end{abstract}

Kata kunci : Tepung ubi jalar, medium fermentasi, Lactobacillus casei, Lactobacillus plantarum

\begin{abstract}
The aims of this research was to compare viability of probiotic bacterias like Lactobacillus plantarum and $L$. casei at fermented medium based on sweet potatoes flour and to know the change of flour component of sweet potato from three kinds of sweet potatoes during fermentation process. The treatments were kind of probiotic bacteria (L.casei and L. plantarum) and kind of sweet potato flour (white, yellow and purple sweet potatoes flour). Based on the result the kind of sweet potatoes influenced the viability of Lactobacillus casei and Lactobacillus plantarum during fermentation process. Sweet potato flour significantly affected $\mathrm{pH}$ value, total acid, total $\mathrm{LAB}$, reductive sugar, while various probiotic bacterias significantly affected $\mathrm{pH}$ value, total acid, total $\mathrm{LAB}$, total sugar, crude fibre, reductive sugar and total $\mathrm{N}$ and starch content. The best treatment was fermented medium that was consisted of purple sweet potato flour $(10 \% \mathrm{~b} / \mathrm{v})$ and $L$. plantarum, with the total value of $\mathrm{LAB}$ was $1.55 \times 10^{10}$ CFU $/ \mathrm{ml}$, total acid was $0.953 \%$, pH value was 4.267 , and total sugar $1.647 \%$, starch content was $2.567 \%$, crude fibre was $0.066 \%$, reductive sugar was $3.139 \%$, and total $\mathrm{N}$ was $0.023 \%$.
\end{abstract}

\section{Keyword: Sweet Potato Flour, Fermented Medium, Lactobacillus casei, Lactobacillus plantarum}

\begin{abstract}
Pendahuluan
Seiring dengan peningkatan kesadaran masyarakat terhadap kesehatan, saat ini pangan fungsional semakin banyak diminati oleh masyarakat luas. Menurut Clydesdale, 1999, pangan fungsional adalah pangan yang karena kandungan komponen aktifnya dapat memberikan manfaat kesehatan. Salah satu pangan fungsional yang berkembang pesat adalah pangan probiotik. Menurut Salminen et al. (1999), probiotik merupakan sel atau komponen mikrobia yang memberikan efek kesehatan dengan menyeimbangkan mikrobia pencernaan serta memiliki viabilitas tinggi pada saluran pencernaan. Pangan probiotik pada umumnya berbasis susu misalnya susu fermentasi,
\end{abstract}

yoghurt dan keju. Saat ini belum banyak dikembangkan pangan fermentasi probiotik berbasis umbi-umbian.

Ubi-ubian khususnya ubi jalar cocok digunakan sebagai medium fermentasi, dimana ubi mengandung kandungan nutrisi yang tinggi seperti kadar gula serta komponen serat larut diantaranya golongan oligosakarida termasuk raffinosa, verbakosa dan stakhiosa, yang berpotensi sebagai prebiotik yakni senyawa substrat yang mampu menstimulir pertumbuhan probiotik. Prebiotik merupakan bahan pangan yang tidak tercerna dan menguntungkan mikroflora usus dengan menstimulasi secara selektif pertumbuhan dan aktivitas satu atau lebih bakteri yang 
terdapat dalam kolon (usus besar) sehingga meningkatkan kesehatan usus (Suskovic et al., 2001).

Serat pangan yang terdapat pada ubi jalar dapat berfungsi sebagai prebiotik bagi bakteri probiotik melalui proses fermentasi, sehingga dihasilkan efek sinbiotik. Hasil ini akan meningkatkan pemanfaatan ubi jalar sebagai bahan pangan yang bernilai gizi tinggi dan bersifat pangan fungsional. Golongan Lactobacilus termasuk salah satu jenis bakteri probiotik. Lactobacillus menghasilkan asam lemak rantai pendek (SCFA) terutama asetat, propionat, dan butirat. Begitu pula dengan potensi prebiotik berupa serat larut pada ubi jalar yang nantinya dapat mendukung pertumbuhan bakteri probiotik menghasilkan efek sinbiotik. Salah satu probiotik komersial yang ada yaitu Lactobacillus casei dan L. plantarum

Menurut Rizzani (2008), medium fermentasi ubi jalar ungu (bentuk tepung dalam air) lebih cepat meningkatkan jumlah sel bakteri probiotik. Probiotik Lactobacillus acidophilus menunjukkan petumbuhan yang lebih cepat pada medium fermentasi ubi ungu dibandingkan pada medium susu, hal ini ditunjukkan dengan penurunan $\mathrm{pH}$ awal (normal) sampai 4,5 dalam jangka waktu 12 jam sedangkan pada medium susu penurunan sampai $\mathrm{pH}$ 4,5 dicapai dalam waktu 66 jam.

Permasalahan yang dihadapi dalam penelitian pengembangan ubi sebagai medium fermentasi adalah belum diketahuinya jenis isolat (L.casei dan $L$. plantarum) yang berpotensi memiliki viabilitas tinggi pada medium ubi-ubian. Selain itu, penelitian sebelumnya baru sampai mempelajari kemampuan isolat L.acidophilus pada salah satu jenis ubi saja. Dimana untuk jenis varietas ubi memiliki perbedaan komponen sehingga dimungkinkan perubahan komponen yang berbeda selama fermentasi. Oleh karena itu, penelitian ini ditujukan untuk mengenai kemampuan pertumbuhan isolat $L$. casei dan $L$. plantarum pada medium fermentasi berbasis ubi putih (var. melati), ubi kuning (var. sari), dan ubi ungu (var. Ayamurasaki).

\section{Materi dan Metode \\ Materi}

Bahan yang dipergunakan antara lain bakteri Lactobacillus casei dan Lactobacillus plantarum yang diperoleh dari Laboratorium Mikrobiologi Teknologi Hasil Pertanian (THP) Universitas Brawijaya (Unibraw) Malang. Ubi ungu jepang (Ipomoea batatas var. Ayamurasaki), ubi putih varietas gunung kawi (diperoleh dari Pasar Karanglo Malang), ubi kuning varietas sari (diperoleh dari Sentra Pengembagan Agribisnis Terpadu Lawang), MRS Broth merk Oxoid, MRS Agar merk Pronadisa, Pepton, alkohol $70 \%$ (toko Medi Lab), yodium $1 \%$, larutan $\mathrm{NaOH} 0,1 \mathrm{~N}$, asam oksalat, $\mathrm{Na}_{2} \mathrm{SO}_{4}$ buffer $\mathrm{pH} 4$ dan $\mathrm{pH} 7$, indikator $\mathrm{PP}$, reagen biuret, larutan $\mathrm{TCA}$, alkohol $10 \%$, eter, $\mathrm{HCL}$ $25 \%, \quad \mathrm{NaOH} 45 \%$, larutan $\mathrm{H}_{2} \mathrm{SO}_{4}$ pekat, glukoseanhidrat, asam metafosforat, larutan pereduksi anthrone, larutan nelson, larutan arseno-molibdat (Laboratorium Biokimia dan Nutrisi THP), aquadest (Laboratorium Kimia Unibraw), kloroform, metanol, enzim alfa amilase, etanol 95\%, etanol 78\%, air PDAM, kertas payung, plastik, karet, kapas, kertas saring whatman.

Bahan-bahan kimia yang dipergunakan dalam penelitian ini adalah bahan kimia untuk analisa total BAL, pH, total asam, kadar air, kadar abu, pati, total gula, gula reduksi, total N, SCFA, serat kasar, dan serat NDF.

Alat yang digunakan antara lain laminar air flow, vortex - mixer model VM - 2000, inkubator (Binder BD53 Jerman), timbangan digital (Denver Instrumen M310), waterbath, refrigerator (Ruey Shing), $\mathrm{pH}$ meter (model pHS-3C), cabinet dryer, muffle furnace, oven kering, sentrifuge "Heittich mikro 22R", autoklaf (HL-36 AE Hiramaya, Jepang), spektrofotometer (Unico UV2100 Spectrophotometer), mikropipet (Finnpipette, Labsystem), ependoff, tip, kompor gas, kompor listrik, beker glass, erlenmeyer, tabung reaksi, cawan petri, pipet tetes, pipet volume, bunsen, ose, sendok, panci, spatula, kain saring, termometer, HPLC D-7000, desikator, pendingin tegak, filter gelas 2-6-3, tanur.

\section{Metode}

Penelitian ini menggunakan Rancangan Acak Kelompok dengan dua faktor yaitu jenis tepung ubi (tepung ubi ungu, tepung ubi kuning, tepung ubi putih) dan jenis isolat (Lactobacillus casei dan Lactobacillus plantarum) dengan 3 kali ulangan. Faktor pertama, U1 = Tepung ubi putih $10 \%(\mathrm{~b} / \mathrm{v})$, U2 = Tepung ubi kuning $10 \%$ (b/v), U3 = Tepung ubi ungu $10 \%$ (b/v), sedangkan faktor kedua, L1 = Lactobacillus casei, L2 = Lactobacillus plantarum. Dengan demikian kombinasi perlakuan adalah: U1L1 = Tepung ubi putih $10 \%$ (b/v) dan Lactobacillus casei; U2L1 = Tepung ubi kuning $10 \%(\mathrm{~b} / \mathrm{v})$ dan Lactobacillus casei; U3L1 = Tepung ubi ungu $10 \%$ (b/v) dan Lactobacillus casei U1L2 = Tepung ubi putih $10 \%$ (b/v) dan Lactobacillus plantarum; U2L2 = Tepung ubi kuning $10 \%$ (b/v) dan Lactobacillus plantarum; U3L2 = Tepung ubi ungu $10 \%$ (b/v) dan Lactobacillus plantarum

\section{Pembuatan tepung ubi}

Ubi diseleksi untuk diperoleh ubi dengan kualitas yang bagus (penyortiran), lalu diikuti dengan pengupasan dan pengecilan ukuran. Pengeringan dilakukan pada suhu $55-60^{\circ} \mathrm{C}$ selama 24 jam, dan diikuti dengan proses penggilingan dan pengayakan $ø 60$ mesh.

Pembuatan medium fermentasi berbasis tepung ubi

Tepung ubi dilarutkan dalam air dengan konsentrasi $10 \%(\mathrm{~b} / \mathrm{v})$. Kemudian dilakukan pemanasan pada suhu $70^{\circ} \mathrm{C}$ selama 15 menit. Setelah homogen, dilakukan sterilisasi pada suhu $121^{\circ} \mathrm{C}$ selama 15 menit. Setelah dingin, dilakukan diinokulasi Lactobacillus casei dan L. Plantarum (2\% v/v). Medium fermentasi tepung ubi kemudian diinkubasi pada suhu $37^{\circ} \mathrm{C}$, selama 12 jam.

Analisa medium fermentasi meliputi total Bakteri Asam Laktat (Lactobacillus casei dan L. plantarum), $\mathrm{pH}$, total asam, total gula, gula reduksi, kadar pati, serat 
Tabel 1. Hasil Analisa Kimiawi Tepung Ubi Jalar

\begin{tabular}{|c|c|c|c|c|c|c|c|c|}
\hline Jenis Tepung Ubi & $\begin{array}{c}\text { Kadar air } \\
(\%)\end{array}$ & $\begin{array}{c}\text { Kadar abu } \\
(\%)\end{array}$ & $\begin{array}{c}\text { Gula } \\
\text { Reduksi } \\
(\%)\end{array}$ & $\begin{array}{c}\text { Total Gula } \\
(\%)\end{array}$ & Pati (\%) & $\begin{array}{c}\text { Serat } \\
\text { Kasar (\%) }\end{array}$ & $\begin{array}{c}\text { Protein } \\
(\%)\end{array}$ & $\begin{array}{c}\mathrm{N} \text { total } \\
(\%)\end{array}$ \\
\hline Ubi Jalar Putih & 1,74 & 0,20 & 24,12 & 40,24 & 54,52 & 0,70 & 2,56 & 0,41 \\
\hline Ubi Jalar Kuning & 1,46 & 0,21 & 24,74 & 40,31 & 54,48 & 0,85 & 2,69 & 0,43 \\
\hline Ubi Jalar Ungu & 0,90 & 0,20 & 25,01 & 40,45 & 54,61 & 0,90 & 2,94 & 0,47 \\
\hline
\end{tabular}

Keterangan:

Faktor konversi protein $=$ tepung ubi ungu $=6,25$

Tabel 2. Rerata Hasil Analisa Medium Fermentasi Tepung Ubi Sebelum Fermentasi

\begin{tabular}{|c|c|c|c|c|c|c|c|c|c|}
\hline Jenis Ubi & Jenis Isolat & $\begin{array}{c}\mathrm{BAL} \\
(\mathrm{CFU} / \mathrm{ml})\end{array}$ & $\begin{array}{c}\text { Total } \\
\text { Asam } \\
(\%)\end{array}$ & $\mathrm{pH}$ & $\begin{array}{c}\text { Total } \\
\text { Gula (\%) }\end{array}$ & Pati(\%) & $\begin{array}{c}\text { Serat } \\
\text { kasar(\%) }\end{array}$ & $\begin{array}{c}\text { Gula } \\
\text { Reduksi } \\
(\%)\end{array}$ & $\begin{array}{c}\text { Total N } \\
(\%)\end{array}$ \\
\hline \multirow[t]{2}{*}{ Ubi Putih } & L.casei & $1,16 \times 10^{8}$ & 0,06 & 5,67 & 3,800 & 4,270 & 0,094 & 2,796 & 0,045 \\
\hline & L.plantarum & $1,35 \times 10^{8}$ & 0,06 & 5,67 & 3,763 & 4,283 & 0,094 & 2,752 & 0,044 \\
\hline \multirow[t]{2}{*}{ Ubi Kuning } & L.casei & $9,33 \times 10^{7}$ & 0,06 & 5,60 & 3,810 & 4,260 & 0,096 & 2,730 & 0,045 \\
\hline & L.plantarum & $1,43 \times 10^{8}$ & 0,07 & 5,63 & 3,853 & 4,300 & 0,093 & 2,882 & 0,048 \\
\hline \multirow[t]{2}{*}{ Ubi Ungu } & L.casei & $1,09 \times 10^{8}$ & 0,12 & 5,70 & 3,903 & 4,270 & 0,098 & 2,954 & 0,047 \\
\hline & L.plantarum & $2,01 \times 10^{8}$ & 0,16 & 5,70 & 3,950 & 4,283 & 0,098 & 2,932 & 0,047 \\
\hline
\end{tabular}

kasar, dan $\mathrm{N}$ total. Analisa dilakukan pada fermentasi jam ke- 0 dan jam ke- 6 . Total gula metode Anthrone (Apriyantono et al., 1989), kadar pati metode Direct Acid Hydrolysis menurut AOAC kadar serat kasar metode oven menurut, kadar gula reduksi menurut, dan kadar N-Total metode Kjeldhal menurut (AOAC, 1990, Sudarmadji et al., 1997).

\section{Hasil dan Pembahasan}

\section{Analisa Bahan Baku}

Data pada Tabel 1 terlihat bahwa kadar pati lebih rendah daripada total gula yang terkandung dalam tepung ubi ungu. Hal tersebut diduga karena bahan baku (ubi ungu jepang) yang akan diolah menjadi tepung sudah mengalami pematangan selama penyimpanan. Selama waktu penyimpanan (pasca panen), ubi ungu mengalami proses metabolisme sehingga dapat mengakibatkan perubahan komponen non air terutama pati menjadi gula-gula yang lebih sederhana, sementara laju respirasi dan transpirasi dapat ditekan sehingga secara prosentase gula yang terbentuk dari perombakan pati akan terakumulasi, sehingga total gulanya meningkat. Widjanarko (1991) dalam Daniawan (2007), menyatakan bahwa respirasi merupakan perombakan bahan-bahan yang komplek.

Tepung ubi dalam medium fermentasi akan meningkatkan ketersediaan nutrisi berupa komponen total gula, kadar pati, dan kadar serat kasar. Menurut Lewthwaite et al., (1997) kandungan total gula yang ada pada tiap kultivar ubi berbeda-beda tergantung pada hasil persilangan ubi, umur panen, penyimpanan pasca panen, dan proses pemasakan yang dapat mengkonversikan pati menjadi gula-gula sederhana.

Sedangkan bakteri asam laktat dalam medium akan memfermentasi atau menghidrolisis gula menjadi komponen-komponen yang lebih sederhana kemudian menjadi asam laktat, asam organik, $\mathrm{CO}_{2}, \mathrm{H}_{2} \mathrm{O}$ dan energi. Kemampuan dari masing-masing isolat $\mathrm{BAL}$ dalam memecah komponen makronutrien menjadi komponen yang paling sederhana selama fermentasi berbeda-beda. dalam sel (pati, gula dan asam-asam organik) dengan bantuan oksigen (oksidasi) menjadi molekul yang lebih sederhana seperti $\mathrm{CO}_{2}, \mathrm{H}_{2} \mathrm{O}$ energi dan molekul baru lainnya yang bisa digunakan oleh sel dalam biosintesa.

Tabel 1 juga menunjukkan bahwa susu skim yang digunakan dalam penelitian ini memiliki kadar total gula dan protein yang hampir mendekati literatur. Menurut Hadiwiyoto (1994), beberapa faktor yang mempengaruhi perbedaan komposisi susu yang dihasilkan, antara lain jenis hewan dan keturunannya, pertumbuhannya, umur hewan dan panjang masa laktasi, kesehatan hewan, jenis dan macam pakan, pengaruh musim, dan manajemen pemerahan.

\section{Analisa Media Ubi Sebelum Fermentasi}

Berdasarkan Tabel 2. Menunjukkan bahwa jenis tepung ubi berpengaruh nyata terhadap nilai $\mathrm{pH}$, kadar total gula dan kadar pati dan berpengaruh sangat nyata terhadap total asam. Jenis isolat berpengaruh sangat nyata terhadap kadar gula reduksi, kadar pati, kadar total nitrogen, pati dan berpengaruh nyata terhadap total asam. Jenis tepung ubi dan jenis isolat berpengaruh sangat nyata $(a=0,01)$ pada total asam, nilai $\mathrm{pH}$, dan kadar pati dalam medium fermentasi.

\section{.Total Bakteri Asam Laktat}

Rerata total bakteri asam laktat pada jam ke-0 berkisar antara $9,33 \times 10^{7}-2,01 \times 10^{8} \mathrm{CFU} / \mathrm{ml}$. Setelah fermentasi (6 jam), rerata jumlah bakteri asam laktat menjadi $5,20 \times 10^{9}-1,55 \times 10^{10} \mathrm{CFU} / \mathrm{ml}$ Pengaruh perbedaan jenis tepung ubi dan jenis isolat terhadap pertumbuhan bakteri asam laktat dapat dilihat pada Gambar 1.

Gambar 1 menunjukkan adanya kecenderungan peningkatan pertumbuhan total bakteri asam laktat selama fermentasi dari jam ke-0 sampai akhir fermentasi jam ke-6. Rerata peningkatan jumlah total bakteri asam laktat pada perlakuan media fermentasi tepung ubi putih dengan menggunakan isolat Lactobacillus casei menunjukkan peningkatan total BAL yang terendah $\left(5,08 \times 10^{9} \mathrm{CFU} / \mathrm{ml}\right)$ sedangkan pada 
perlakuan media fermentasi tepung ubi ungu dengan isolat Lactobacillus plantarum adalah yang tertinggi $\left(1,53 \times 10^{10} \mathrm{CFU} / \mathrm{ml}\right)$. Data ini menunjukkan bahwa pada semua perlakuan terjadi peningkatan total bakteri asam laktat selama fermentasi. Bakteri asam laktat dalam medium akan memfermentasi atau menghidrolisis gula menjadi komponen-komponen yang lebih sederhana menjadi asam laktat, asam organik, $\mathrm{CO}_{2}, \mathrm{H}_{2} \mathrm{O}$ dan energi. Selanjutnya energi digunakan untuk sintesis sehingga terjadi kenaikan jumlah sel. Selama proses fermentasi, bakteri asam laktat memetabolisme kandungan nutrisi yang banyak terdapat pada tepung ubi jalar yang akan digunakan untuk pertumbuhan sel.

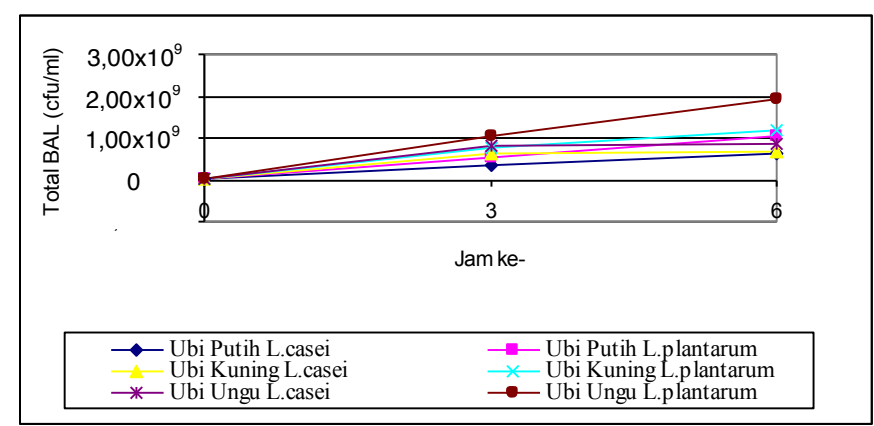

Gambar 1. Pengaruh Jenis Isolat dan Tepung Ubi Terhadap Pertumbuhan BAL Selama Fermentasi

\section{Total Asam}

Rerata total asam pada medium fermentasi terhitung sebelum fermentasi berkisar antara $0,16 \%$ $0,26 \% \%$. Rerata total asam medium fermentasi terhitung pada akhir fermentasi (6 jam) berkisar antara $0,71 \%-0,95 \%$. Total asam medium fermentasi selama waktu inkubasi akibat perlakuan penambahan jenis isolat dan jenis tepung ubi dapat dilihat pada Gambar 2.

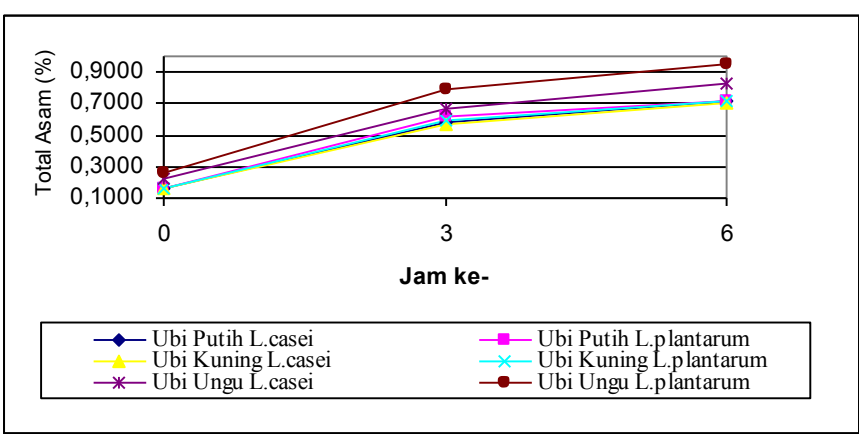

Gambar 2. Pengaruh Jenis Isolat dan Jenis Tepung Ubi Terhadap Total Asam Medium Fermentasi Berbasis Tepung Ubi Selama Proses Fermentasi

Gambar 2 memperlihatkan adanya peningkatan total asam medium fermentasi selama fermentasi pada semua perlakuan jenis ubi dan isolat BAL. Hasil analisa ragam menunjukkan baik perlakuan jenis medium fermentasi tepung ubi, jenis isolat BAL, maupun interaksi antara keduanya berpengaruh nyata $(a=0,05)$.

Peningkatan total asam terendah pada perlakuan jenis medium fermentasi tepung ubi kuning dengan isolat BAL Lactobacillus casei $(0,55 \%)$ dan tertinggi adalah pada perlakuan medium fermentasi tepung ubi ungu dengan isolat BAL Lactobacillus plantarum $(0,69 \%)$.

Tingginya jumlah Lactobacillus plantarum ini berpengaruh terhadap peningkatan asam laktat yang dihasilkan. Asam laktat dan asetaldehid yang dihasilkan dari pemecahan glukosa oleh $L$. plantarum menyebabkan penurunan $\mathrm{pH}$ medium yang besar atau meningkatkan keasaman (Spreer,1998). Selama proses fermentasi, bakteri asam laktat mengubah glukosa menjadi asam laktat melalui Embden Meyerhoff Pathway (EMP). Terakumulasinya asam laktat ini menyebabkan tingkat keasaman medium fermentasi akan meningkat. Pada media dengan sumber utama glukosa dan laktosa, asam laktat yang dihasilkan adalah sekitar $90 \%$ dari produk akhir. Berbagai monosakharida dimetabolisme oleh bakteri asam laktat menjadi glucose-6-phosphate atau fructose-6phosphate dan kemudian terjadi metabolisme melalui jalur Embden Meyerhoff Parnas (EMP) yang pada akhirnya dihasilkan asam laktat (Surono, 2004). Peningkatan total asam sebagai hasil metabolisme sel semakin meningkat dengan semakin meningkatnya jumlah total BAL (Lactobacillus casei dan Lactobacillus plantarum).

Hubungan regresi linear antara peningkatan total asam dengan peningkatan total BAL (Lactobacillus casei dan L. plantarum) menunjukkan korelasi positif dan mengikuti persamaan $y=1.10^{-11} x+0,4704$ dengan determinasi 0,7238 . Dari determinasi tersebut diketahui bahwa $72,38 \%$ total asam dipengaruhi oleh total BAL. Semakin banyak jumlah sel Lactobacillus casei dan $L$. plantarum yang ada maka total asam sebagai hasil metabolisme sel juga semakin besar. Hal ini disebabkan karena semakin banyak BAL maka pembentukan asam juga semakin besar.

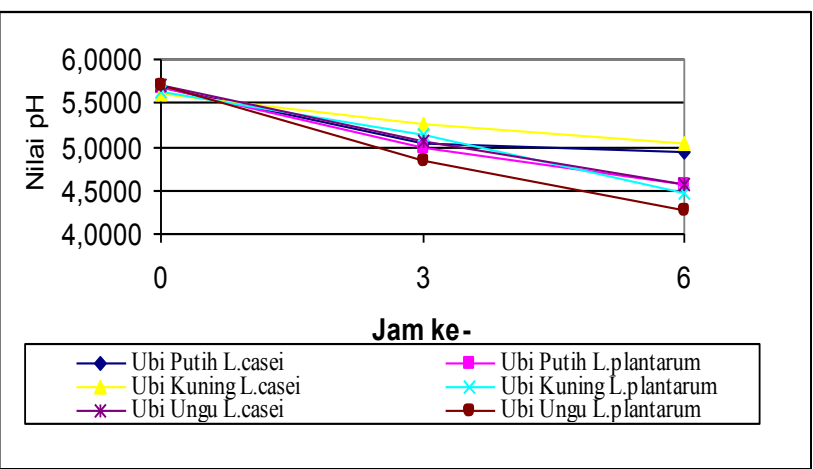

Gambar 3. Pengaruh Jenis Isolat dan Jenis Tepung Ubi Terhadap Derajat Keasaman $(\mathrm{pH})$ Medium Fermentasi

\section{Derajat Keasaman $(\mathrm{pH})$}

Rerata derajat keasaman $(\mathrm{pH})$ pada medium fermentasi terhitung pada sebelum fermentasi berkisar antara 5,6 - 5,7. Rerata derajat keasaman $(\mathrm{pH})$ pada medium fermentasi terhitung pada akhir fermentasi (6 jam) berkisar antara 4,27 - 5,03. Derajat keasaman $(\mathrm{pH})$ medium fermentasi selama waktu inkubasi akibat perlakuan jenis tepung ubi dan jenis isolat dapat dilihat pada Gambar 3.

Gambar 3 menunjukkan adanya penurunan $\mathrm{pH}$ medium fermentasi selama proses fermentasi dari jam 
ke-0 sampai jam ke-6 pada semua perlakuan jenis ubi dan isolat BAL. Penurunan $\mathrm{pH}$ terendah adalah pada perlakuan jenis medium fermentasi tepung ubi kuning dengan isolat BAL $L$. casei $(0,57)$ dan tertinggi adalah jenis medium fermentasi tepung ubi ungu dengan isolat BAL L. plantarum $(1,43)$. Pada semua perlakuan menunjukkan bahwa selama fermentasi terjadi penurunan $\mathrm{pH}$. Jumlah asam organik yang tinggi selama fermentasi dapat menyebabkan terjadinya penurunan derajat keasaman. Charalampopoulus et al. (2002) menyatakan bahwa akumulasi asam yang dihasilkan melalui metabolisme bakteri asam laktat dapat menurunkan $\mathrm{pH}$ medium. Meskipun akumulasi asam yang dihasilkan bakteri asam laktat dapat menurunkan $\mathrm{pH}$ tapi penurunan $\mathrm{pH}$ tidak selalu sesuai dengan banyaknya akumulasi asam.

Anafia (1997) menyatakan bahwa penurunan $\mathrm{pH}$ merupakan salah satu akibat proses fermentasi yang terjadi karena adanya akumulasi asam laktat sebagai produk utama dari aktivitas bakteri yang bersifat homofermentatif. Menurut Bordignon et al. (2004) Lactobacillus yang bersifat homofermentatif menghasilkan $90 \%$ asam laktat dari metabolisme glukosa. Walaupun kedua jenis isolat BAL yaitu $L$. casei dan $L$. plantarum sama-sama merupakan bakteri homofermentatif tetapi kemampuan masing-masing isolat dalam menghidrolisis komponen nutrisi pada medium ubi berbeda. Penurunan $\mathrm{pH}$ semakin meningkat dengan meningkatnya total asam sebagai hasil metabolisme bakteri $L$. casei dan $L$. plantarum.

Hubungan regresi linear antara penurunan derajat keasaman $(\mathrm{pH})$ dengan peningkatan total $\mathrm{BAL}$ menunjukkan korelasi positif dan mengikuti persamaan $y=7.10^{-11} x+0,4291$ dengan determinasi 0,7302 Dari determinasi tersebut diketahui bahwa 73,02 \% derajat keasaman $(\mathrm{pH})$ dipengaruhi total BAL. Hal ini kemungkinan disebabkan karena analisa $\mathrm{pH}$ bergantung pada jumlah atom $\mathrm{H}^{+}$yang terdisosiasi, sementara atom $\mathrm{H}^{+}$yang terdisosiasi dari total asam laktat besar sehingga antara $\mathrm{pH}$ dan total bakteri asam laktat tingkat korelasinya besar. Semakin tinggi jumlah sel Lactobacillus maka akan semakin menurunkan derajat keasaman $(\mathrm{pH})$ medium fermentasi.

\section{Total Gula}

Rerata total gula pada medium fermentasi sebelum difermentasi berkisar antara 3,763 - 3,95\%. Setelah fermentasi rerata total gula menjadi 1,61 $1,703 \%$. Total gula sebelum dan sesudah fermentasi dengan perlakuan penambahan jenis tepung ubi dan jenis isolat dapat dilihat pada Gambar 4.

Gambar 4 memperlihatkan nilai kadar total gula medium fermentasi menurun pada semua perlakuan. Rerata penurunan total gula tertinggi pada perlakuan medium fermentasi tepung ubi ungu $10 \%$ dengan isolat $L$ plantarum $(2,303 \%)$ dan terendah pada perlakuan medium fermentasi tepung ubi ungu $10 \%$ dengan isolat L. casei $(2,107 \%)$. Pada semua perlakuan terjadi penurunan kadar total gula selama fermentasi. Hal ini diduga karena terjadi pemanfaatan gula dan polisakarida yang terkandung dalam ubi sebagai sumber karbon dan energi untuk pertumbuhan L.plantarum dan $L$. casei. Penurunan total gula disebabkan hidrolisis pati yang kecil. Hasil hidrolisis pati tersebut yaitu karbohidrat sederhana dimanfaatkan bakteri sebagai sumber energi.

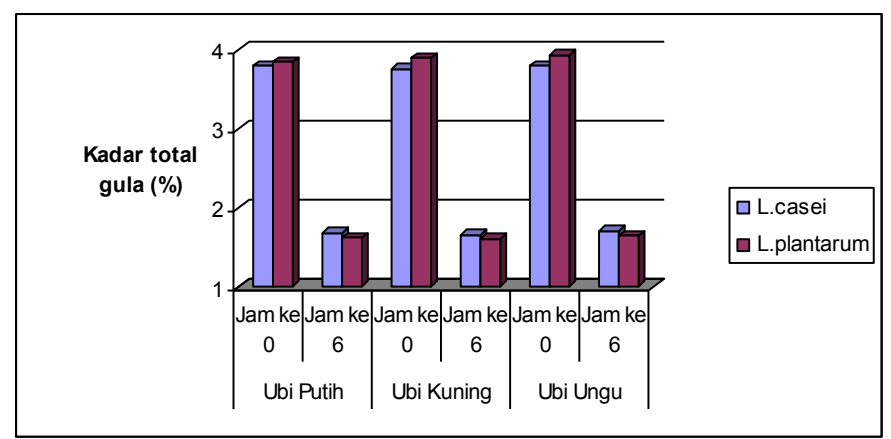

Gambar 4. Pengaruh Jenis Isolat dan Jenis Tepung Ubi Terhadap Total Gula Medium Fermentasi

Hasil analisis ragam memperlihatkan adanya perbedaan sangat nyata $(a=0,01)$ akibat dari perlakuan jenis isolat probiotik terhadap penurunan kadar total gula selama fermentasi, sedangkan perlakuan jenis medium fermentasi tepung ubi tidak berpengaruh nyata terhadap penurunan kadar total gula. Lactobacillus plantarum memberikan penurunan kadar total gula yang lebih tinggi dibanding Lactobcillus casei. Hal ini diduga karena kemampuan Lactobacillus plantarum dalam menggunakan gula-gula sederhana yang ada di dalam tepung ubi lebih baik daripada $L$. casei. Charalampopoulus et al. (2002) mengatakan bahwa Lactobacillus plantarum mampu memanfaatkan gula sederhana sebagai nutrisi sebesar (43\%) sedangkan kemampuan Lactobacillus casei memanfaatkan gula sederhana sebesar (16\%) pada fase eksponensial. Yoon et al. (2004) kultur bakteri asam laktat menyebabkan penurunan level gula pada jus tomat terfermentasi dimana $L$. plantarum mengkonsumsi gula lebih cepat dibanding $L$. casei.

Menurut Oberman (1985), peningkatan jumlah bakteri menyebabkan peningkatan kebutuhan senyawa yang dirombak menjadi asam laktat. Hubungan regresi linier antara penurunan total gula dengan total $\mathrm{BAL}$ menunjukkan korelasi positif dan mengikuti persamaan $y=2 \cdot 10^{-11} x+2,0146$ dengan determinasi 0,7418 . Dari determinasi tersebut dapat diketahui bahwa $74,18 \%$ penurunan total gula dipengaruhi oleh total BAL (Lactobacillus casei dan L. plantarum). Semakin tinggi total BAL (Lactobacillus casei dan L. plantarum) maka penggunaan gula sebagai substrat juga semakin besar.

Pati

Rerata kadar pati pada medium fermentasi sebelum difermentasi berkisar antara 4,26-4,30\%. Setelah fermentasi, rerata kadar pati menjadi 2,567$2,637 \%$. Kadar pati sebelum dan sesudah fermentasi dengan perlakuan penambahan jenis isolat dan jenis tepung ubi dapat dilihat pada Gambar 5.

Gambar 5 memperlihatkan nilai kadar pati medium fermentasi tepung ubi menurun pada semua perlakuan. Rerata penurunan kadar pati selama 
fermentasi tertinggi pada perlakuan medium fermentasi tepung ubi ungu $10 \%$ dengan isolat Lactobacillus plantarum $(1,717 \%)$ dan terendah pada perlakuan medium fermentasi tepung ubi kuning $10 \%$ dengan isolat $L$. casei $(1,647 \%)$. Pada semua perlakuan terjadi penurunan kadar pati selama fermentasi. Hal ini diduga karena kandungan pati yang terdapat dalam medium tepung ubi dapat dipecah oleh isolat Lactobacillus. Menurut Ryan et al. (2006) menyebutkan bahwa beberapa strain BAL telah diteliti memiliki aktivitas amilolitik.

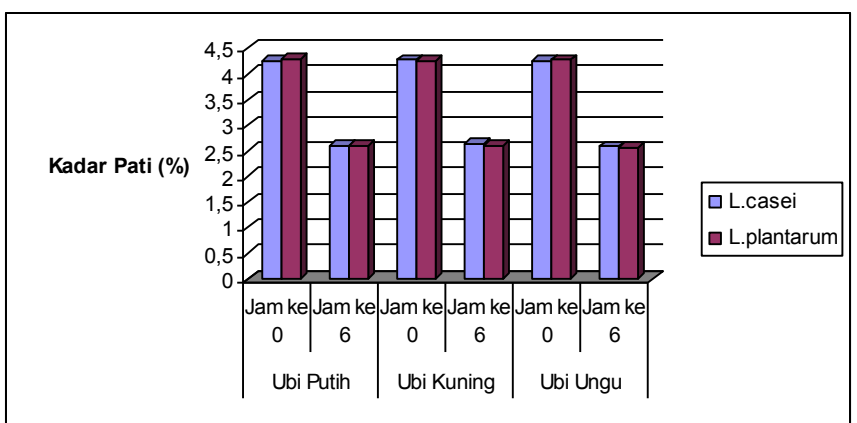

Gambar 5. Pengaruh Jenis Isolat dan Jenis Tepung Ubi Terhadap Kadar Pati Medium Fermentasi

Hasil analisis ragam memperlihatkan adanya perbedaan sangat nyata $(a=0,01)$ akibat dari perlakuan jenis isolat probiotik terhadap penurunan kadar pati selama fermentasi, sedangkan perlakuan jenis medium fermentasi tepung ubi berpengaruh nyata $(a=0,05)$ terhadap penurunan kadar pati. diduga bahwa pada Lactobacillus plantarum memiliki aktivitas amilolitik yang lebih besar, sehingga mampu menghidrolisis pati menjadi komponen yang lebih sederhana dan memanfaatkannya sebagai nutrisinya lebih banyak. Salminen and Wright (1993) menyatakan Lactobacillus plantarum memiliki daya amilolitik yang baik dan dapat memproduksi maltosa, maltotriosa, dan sejumlah kecil glukosa dari amilopektin. Jadi adanya pati menjadikan bakteri asam laktat $L$. plantarum dapat tumbuh dan berkembang dalam medium fermentasi tepung ubi putih, kuning, dan ungu. Kebutuhan nutrisi akan pati semakin meningkat dengan semakin bertambahnya jumlah sel bakteri. Kedua jenis isolat BAL (Lactobacillus casei dan L. plantarum) memberikan penurunan kadar pati yang berbeda. $L$. plantarum memberikan penurunan kadar pati yang lebih tinggi dibanding Lactobacillus casei. Hal ini diduga karena Lactobacillus plantarum memiliki sifat amilolitik yang lebih besar dari $L$. casei dimana bakteri ini mampu memanfaatkan pati sebagai sumber nutrisinya, dan pati tersebut akan terpecah menjadi gula-gula yang lebih sederhana. Selain itu diduga karena enzim yang dihasilkan oleh Lactobacillus plantarum mampu memecah senyawa kompleks menjadi senyawa yang lebih sederhana sehingga dapat dimanfaatkan untuk metabolisme sel. Giraud (1994) telah meneliti $L$. plantarum (strain A6) yang diisolasi dari ketela pohon mampu mensintesa a amilase ekstraseluler dalam jumlah yang banyak. Adanya enzim tersebut menyebabkan isolat $L$. plantarum dapat memecah pati.
Beberapa penelitian menunjukkan bahwa Lactobacillus memiliki daya cerna yang lebih besar terhadap karbohidrat kompleks. Sesuai dengan pernyataan Salminen and Wright (1993) bahwa kelompok Lactobacillus memiliki daya cerna yang besar terhadap karbohidrat kompleks daripada laktosa. Selain itu, walaupun sama-sama dapat memanfaatkan komponen karbohidrat pati, jumlah total bakteri asam laktat juga turut mempengaruhi konsumsi pati oleh kedua isolat. Pemecahan pati semakin meningkat dengan semakin bertambahnya jumlah sel bakteri.

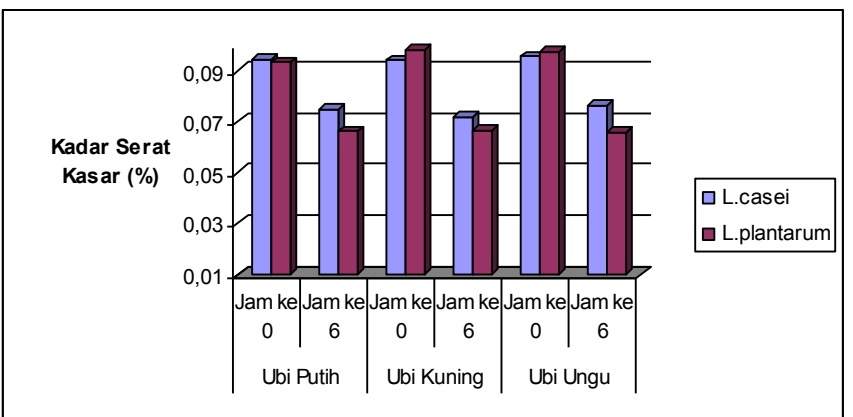

Gambar 6. Pengaruh Jenis Isolat dan Jenis Tepung Ubi Terhadap Kadar Serat Kasar Medium Fermentasi

Hubungan regresi linier antara penurunan kadar pati dengan total BAL (Lactobacillus casei dan Lactobacillus plantarum) menunjukkan korelasi positif dan mengikuti persamaan $y=6.10^{-12} x+1,6252$ dengan determinasi 0,7414 . Dari determinasi tersebut dapat diketahui bahwa $74,14 \%$ penurunan kadar pati dipengaruhi oleh total BAL (Lactobacillus casei dan Lactobacillus plantarum). Semakin tinggi total BAL maka penggunaan pati sebagai substrat juga semakin besar.

\section{Serat Kasar}

Rerata kadar serat kasar medium fermentasi sebelum difermentasi berkisar antara 0,093 - 0,098 \%. Setelah fermentasi, rerata kadar serat kasar menjadi 0,066 -0,077\%. Kadar serat kasar dengan perlakuan jenis isolat dan jenis tepung ubi dapat dilihat pada Gambar 6.

Gambar 6. menunjukkan bahwa kadar serat kasar medium fermentasi tepung ubi (10\%) mengalami penurunan setelah fermentasi pada semua perlakuan. Rerata penurunan kadar serat kasar terendah pada perlakuan medium fermentasi ubi putih dan ubi ungu dengan isolat $L$. casei $(0,019 \%)$ dan tertinggi pada perlakuan medium fermentasi ubi kuning dan ungu dengan isolat Lactobacillus plantarum $(0,032 \%)$. Hasil analisis ragam memperlihatkan adanya perbedaan sangat nyata $(a=0,01)$ akibat dari perlakuan jenis isolat probiotik terhadap penurunan kadar serat kasar selama fermentasi, sedangkan perlakuan jenis medium fermentasi tepung ubi tidak berpengaruh nyata terhadap penurunan kadar serat kasar. Penurunan kadar serat kasar diduga karena adanya pemanfaatan serat kasar oleh aktivitas bakteri asam laktat BAL untuk metabolisme sel. L. plantarum memiliki pengaruh yang lebih besar pada pemanfaatan serat kasar pada 
medium tepung ubi. Selain itu disebabkan karena meningkatnya jumlah bakteri asam laktat turut meningkatkan pemanfaatan serat kasar. Menurut Baron et al. (1989) kedua isolat BAL Lactobacillus plantarum dan $L$. casei merupakan bakteri kolon yang dominan pada usus pencernaan manusia, kedua BAL tersebut memiliki kemampuan yang sangat baik dalam metabolisme, berkembang biak, menghasilkan senyawa-senyawa asam organik dan antibiotik dalam saluran pencernaan manusia. Sehingga kedua mikroorganisme ini banyak digunakan untuk pengembangan produk-produk suplemen kesehatan karena kemampuannya yang sangat baik dalam memfermentasi serat pangan dan prebiotik di dalam kolon, khususnya fruktooligosakarida.

Bakteri BAL memanfaatkan serat kasar yang dihidrolisis menjadi asam laktat, asam lemak rantai pendek, dan energi. Asam lemak rantai pendek (SCFA) yaitu asam asetat, asam propionat, dan asam butirat merupakan hasil utama dari fermentasi serat pangan (Miller and Wollin, 1996). Roberfroid (1998), menyatakan bahwa bakteri asam laktat mempunyai kemampuan memfermentasi selulosa menjadi SCFA. $\mathrm{Di}$ dalam saluran pencernaan manusia, polisakarida pati yang tidak tercerna di usus halus akan dihidrolisa dalam kondisi anaerob dalam usus besar oleh bakteri menjadi unit-unit monomernya seperti glukosa. Kemudian monomer tersebut difermentasi melalui glikolisis menjadi piruvat yang seterusnya menjadi SCFA dan metabolit yang lain (Cumming and Englyst, 1987; Khattak, 2002). Pemanfaatan serat kasar semakin meningkat dengan semakin meningkatnya total BAL (Lactobacillus casei dan L. plantarum).

Hubungan regresi linier antara penurunan kadar serat kasar dengan total BAL (Lactobacillus casei dan L. plantarum) menunjukkan korelasi positif dan mengikuti persamaan $y=1.10^{-12} x+0,0145$ dengan determinasi 0,6835. Dari determinasi tersebut dapat diketahui bahwa 68,35 \% penurunan kadar serat kasar dipengaruhi oleh total BAL (Lactobacillus casei dan L. plantarum). Semakin tinggi total BAL (Lactobacillus casei dan $L$. plantarum) maka penggunaan serat kasar sebagai substrat juga semakin besar.

\section{Gula Reduksi}

Rerata kadar gula reduksi medium sebelum difermentasi berkisar antara 2,730-2,954 \%. Rerata kadar gula reduksi medium setelah fermentasi menjadi $2,923-3,16 \%$. Kadar gula reduksi medium fermentasi akibat penambahan tepung ubi dan jenis isolat dapat dilihat pada Gambar 7.

Gambar 7 memperlihatkan adanya kenaikan gula reduksi pada tiap level perlakuan setelah medium difermentasi. Rerata kenaikan kadar gula reduksi terendah pada medium ubi putih yang terfermentasi oleh $L$. casei $(0,129 \%)$ dan tertinggi yaitu pada medium fermentasi ubi ungu dengan isolat $L$. plantarum $(0,207 \%)$. Selama fermentasi, bakteri asam laktat mempunyai batasan optimum untuk menggunakan glukosa sebagai sumber energi dan karbon sehingga tidak semua glukosa yang ada diubah menjadi asam laktat (terbentuk sisa). Glukosa sisa yang terbentuk adalah gula reduksi.

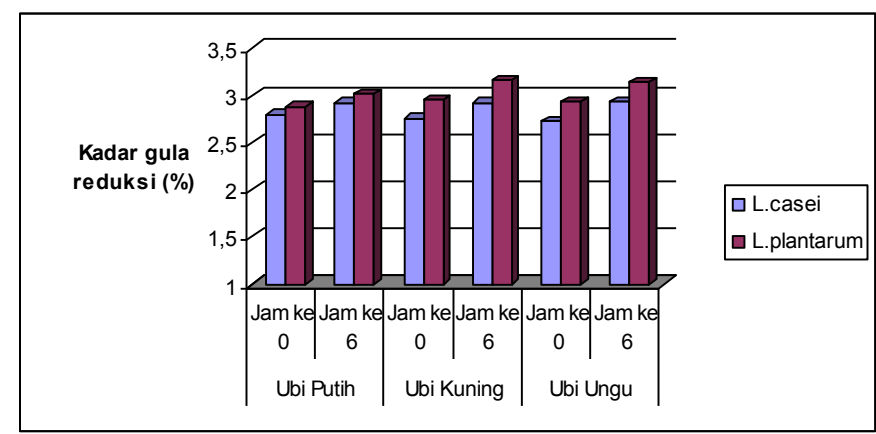

Gambar 7. Pengaruh Jenis Isolat dan Jenis Tepung Ubi Terhadap NTotal Medium Fermentasi

Perlakuan jenis medium ubi dan jenis isolat berpengaruh nyata pada kenaikan kadar gula reduksi medium ubi. Hal ini diduga, selama fermentasi terjadi perombakan pati dan oligosakarida pada serat ubi yang termanfaatkan sebagai sumber energi dalam metabolisme sel.

Hasil analisis ragam memperlihatkan adanya perbedaan nyata $(a=0,05)$ akibat dari perlakuan jenis medium fermentasi tepung ubi terhadap peningkatan kadar gula reduksi setelah fermentasi, sedangkan perlakuan jenis isolat probiotik tidak berpengaruh nyata terhadap peningkatan kadar gula reduksi.

Pengaruh jenis tepung ubi tertinggi pada analisa kadar gula reduksi terjadi pada medium fermentasi ubi ungu. Diduga, adanya peranan serat yang besar dalam tepung ubi ungu selama fermentasi terhidrolisis menjadi gula sederhana sehingga dimungkinkan terjadi peningkatan gula reduksi. Komponen gula sederhana ini, selanjutnya akan langsung dimanfaatkan sebagai sumber energi dalam proses metabolisme sel.

\section{Kadar N-Total}

Rerata kadar $\mathrm{N}$-total medium sebelum fermentasi berkisar antara 0,044-0,048 \%. Sedangkan rerata kadar $\mathrm{N}$ total setelah fermentasi berkisar menjadi $0,023-0,027 \%$. Rerata kadar $\mathrm{N}$ total sebelum dan sesudah fermentasi dengan perlakuan jenis isolat dan jenis medium ubi dapat dilihat pada Gambar 8.

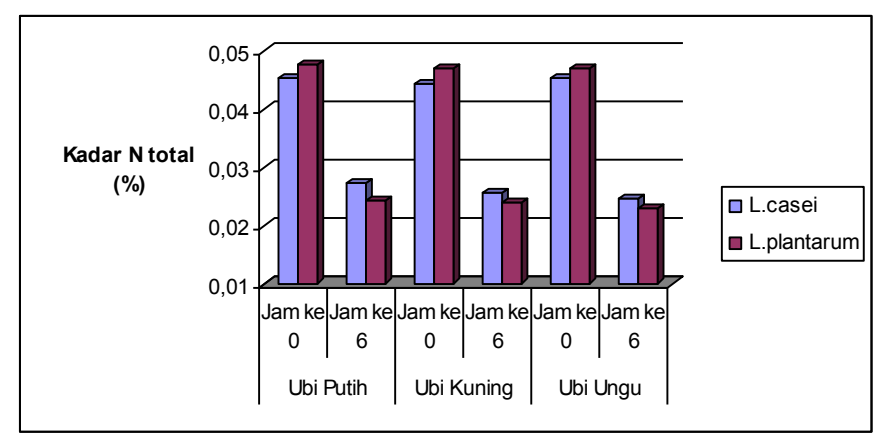

Gambar 8. Pengaruh Jenis Isolat dan Jenis Tepung Ubi Terhadap NTotal Medium Fermentasi 
Tabel 3. Data Perhitungan Nilai Terbaik dari Tiga Parameter yang Dipilih

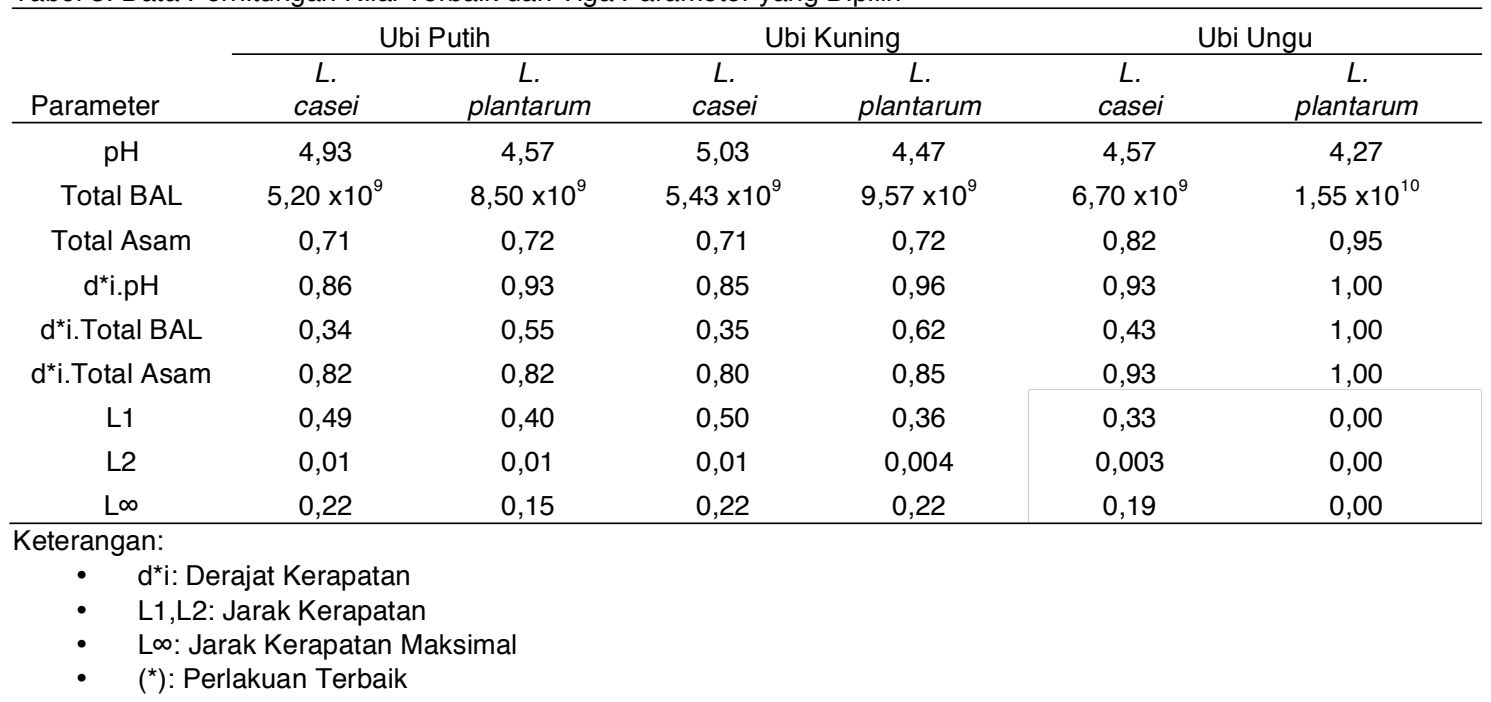

Gambar 8 memperlihatkan nilai kadar $\mathrm{N}$ total medium fermentasi menurun pada semua perlakuan. Rerata penurunan $\mathrm{N}$ total terendah pada perlakuan medium fermentasi ubi putih dengan isolat BAL Lactobacillus casei $(0,018 \%)$ dan tertinggi pada perlakuan medium fermentasi ubi ungu dengan isolat BAL Lactobacillus plantarum $(0,024 \%)$.

Hasil analisis ragam memperlihatkan adanya perbedaan sangat nyata $(a=0,01)$ akibat dari perlakuan jenis isolat probiotik terhadap penurunan kadar $\mathrm{N}$ total selama fermentasi, sedangkan perlakuan jenis medium fermentasi tepung ubi tidak berpengaruh nyata terhadap penurunan kadar $\mathrm{N}$ total. $L$. plantarum dimungkinkan dapat memecah komponen protein lebih baik dibanding $L$. casei. Khalid (2008) mengatakan bahwa L. plantarum memiliki kemampuan proteolitik yang lebih baik dibandingkan $L$. casei. Salah satunya dapat mendegradasi beta kasein lebih baik. Penurunan $\mathrm{N}$ total terjadi diduga karena selama fermentasi, terjadi perombakan protein menjadi asam amino dan peptida (senyawa yang lebih sederhana) oleh mikroba. Kandungan asam amino dan peptida penyusun protein dalam medium fermentasi dapat mempengaruhi penurunan $\mathrm{N}$ total selama fermentasi.

Menurut Fardiaz (1992), selama fermentasi, protein akan dimetabolisme menjadi senyawa-senyawa volatil dan amonia yang akan dilepaskan dalam jumlah yang tinggi pada proses fermentasi lebih lanjut degradasi protein sehingga memungkinkan terjadinya penurunan kadar N-Total. Menurut Rizzani (2008), asam amino di dalam sel dibentuk dari hidrolisis ikatan peptida protein oleh peptidase dan akan digunakan untuk pertumbuhan sel. Adanya pemanfaatan asam amino ini menyebabkan penurunan jumlah nitrogen total. Penurunan $\mathrm{N}$ total semakin meningkat dengan semakin banyaknya jumlah total BAL, sehingga berakibat semakin banyak pula asam amino dan peptida yang terbentuk.

Hubungan regresi linier antara penurunan total $\mathrm{N}$ dengan total BAL (Lactobacillus casei dan L. plantarum) menunjukkan korelasi positif dan mengikuti persamaan $y=6.10^{-13} x+0,0166$ dengan determinasi 0,6955 . Dari determinasi tersebut dapat diketahui bahwa 69,55 \% penurunan kadar total $\mathrm{N}$ dipengaruhi oleh total BAL (Lactobacillus casei dan L. plantarum). Semakin tinggi total BAL (Lactobacillus casei dan L. plantarum) maka penggunaan total $\mathrm{N}$ sebagai substrat juga semakin besar.

\section{Perlakuan Terbaik}

Pemilihan perlakuan terbaik perlakuan penambahan tepung ubi dan jenis isolat pada medium fermentasi dilakukan dengan metode Multiple Attribute. Perlakuan terbaik dipilih dari nilai jarak terkecil dari parameter yang sudah ditentukan pada masing-masing perlakuan dan berdasarkan parameter jumlah total BAL ( $L$. casei dan $L$. plantarum), total asam, $\mathrm{pH}$, maka penambahan medium tepung ubi ungu dan jenis isolat L. plantarum memiliki jarak kerapatan terkecil dan menjadi perlakuan terbaik. Hal ini diduga karena adanya kesesuaian nutrisi pada penambahan tepung ubi ungu menyebabkan bakteri asam laktat $L$. plantarum dapat memanfaatkannya sebagai sumber energi untuk bermultiplikasi dan metabolisme sel. Hal ini sesuai dengan penelitian Daniawan (2007), kecepatan pertumbuhan BAL dalam proses fermentasi sangat ditentukan oleh kesesuaian kandungan nutrisi yang terdapat pada media fermentasi.

\section{Kesimpulan}

Jenis tepung ubi berpengaruh sangat nyata terhadap parameter total BAL, total asam, nilai $\mathrm{pH}$, gula reduksi dan pati. Sedangkan jenis isolat berpengaruh sangat nyata terhadap parameter total BAL, total asam, nilai $\mathrm{pH}$, serat kasar, gula reduksi, total gula, total nitrogen dan berpengaruh nyata pada parameter kadar pati. Jumlah sel Lactobacillus casei dan Lactobacillus plantarum meningkat pada semua jenis tepung ubi. Tetapi yang paling menunjukkan peningkatan total BAL tertinggi adalah pada perlakuan medium tepung ubi ungu proporsi $10 \%(\mathrm{~b} / \mathrm{v})$ dengan isolat Lactobacillus plantarum. Perlakuan terbaik diperoleh pada perlakuan jenis isolat BAL L.plantarum pada medium fermentasi tepung ubi ungu. 


\section{Daftar Pustaka}

Anafia, R. B. 1997. Pengaruh Penambahan Susu Skim dan Lama Fermentasi Terhadap Resiko Kimia dan Organoleptik Yoghurt Biji Kecipir. Skripsi. Jurusan Teknologi Hasil Pertanian. Unika Widya Karya. Malang

AOAC. 1990. Official Methods of Analisis of The Association of Official Analitycal Chemists. Association of Official Analytical Chemists. Washington, D.C

Apriyanto, A., D. Fardiaz, N. L. Puspita Sari, Sedarwati, dan S. Budiyanto. 1989. Analisa Pangan. Departemen Pendidikan dan Kebudayaan. Direktorat Jendral Pendidikan Tinggi Pusat AntarUniversitas Pangan dan Gizi. IPB. Bogor

Baron, J. M. 1989. Friendly Bacteria. Reserved by The Roger Wyburn Mason and Jack M. Blount Foundation for Eradication of Rheumatoid Disease AKA The Arthritis Trust of America

Bordignon, J. R., K. Nakahara, T. Yoshihashi and S. Nikkuni.2004. Hydrolysis of Isoflavones and Consumption of Oligosaccharides During Lactic Acid Fermentation of Soybean Milk. JARQ 38(4), 259-265

Cappuccino, J.G and N. Sherman. 1983. Microbiology a Laboratory Manual. Advison-Wesley Pub. Comp. Inc. USA

Clausen, M. R. , H. Bonnen, and P. B. Mortensen. 1991. Colonic Fermentation of Dietary fibre to Short Chain Fatty Acids in Patients with Adenomatous Polyps and Colonic Cancer. Department of Medicine A, Righospitalet, University of Copenhagen. Denmark

Charalampopoulos, D., S. S. Pandiella, and C. Webb. 2002. Growth Studies of Potentially Probiotic Lactic Acid Bacteria In Cereal - Based Substrates. Journal of Applied Microbiology. Vol.92. p 851 859

Cumming, J.H., G.T. Mcfarlane, H.N. Englyst. 2001. Prebiotic Digestion and Fermentation. American Journal of Nutrition. p. 415-420

Cylesdale, F., 1997. A proposal for the establishment of scientific criteria for health claims for functional foods. Nutr. Rev: 55: 413-422

Daniawan, I. 2007. Studi Pengembangan Minuman Probiotik Slurry Ubi Jalar Ungu Jepang (Ipomoea batatas I. var. Ayamurasakı) Kajian Lama Penyimpanan Ubi Di Suhu Rendah dan Rasio Ubi : Air. Skripsi. Jurusan Teknologi Hasil Pertanian. Fakultas Teknologi Pertanian. Universitas Brawijaya. Malang

Fardiaz, S. 1992. Mikrobiologi Pangan. PT. Gramedia Pustaka Utama. Jakarta

Giraud, G.R. and C.M. Williams.2000. Funtional Foods, Concept to Product. CRC Press. New York

Hadiwiyoto, S. 1994. Teori dan Prosedur Pengujian Mutu Air susu dan hasil olahannya. Liberty. Yogyakarta
Khalid, M. N. and Elmer H. M. 2008. Proteolytic Activity By Strains L.plantarum and L.casei. Journal Department of Food Science. University Wisconsin. Madison

Khattak, A. K.. 2002. Physiological Effects of Dietary Complex Carbohydrates and Its Metabolites Role in Certain Diseases. Pakistan Journal of Nutrition. 1 (4). P. $161-168$

Lewthwaite, S. L., K. H. Sutton and C. M. Triggs. 1997. Free sugar composition of sweet potato cultivars after storage. New zealand Journal of Crop and Horticultural Sci. 25:33-41

Miller, T. L. and Wolin, J. M. 1996. Pathways of Acetate, Propionate, and Butyrate Formation by The Human Fecal Microbial Flora. Applied and Environmental Microbiology Journal. p. 1589 1592

Oberman, H. 1985. Fermented Milks. In Microbiology of Fermented Foods. Vol. 1 Edited by J. B. Wood. Elsevier Applied Sci. Publ. New York. 167-190

Rahmawati, R. D. 2006. Studi Viabilitas dan Aktivitas Antimikrobial Bakteri Probiotik (Lactobacillus acidophilus) dalam Medium Fermentasi Berbasis Susu dan Bekatul Selama Proses Fermentasi. Skripsi. Jurusan Teknologi Hasil Pertanian. Fakultas Teknologi Pertanian. Universitas Brawijaya. Malang

Ryan, S. M., G. F Fitzgerald, D. Sinderen. 2006. Screening for and Identification of Starch-, Amylopectin-, and Pullulan-Degrading Activities in Bifidobacterial Strains. Department of Microbiology, University College Cork, Western Road, Cork, Ireland

Salminen, S. and A. von Wright. 1993. Lactic Acid Bacteria. Marcell Dekker Inc. New York

Salminen, S. 1999. Probiotics: How should they be define. Trends Food Sci Techno. 10:107-110

Salminen, S and A. V.Wright. 1993. Lactic Acid Bacteria: Microbiology and Functional Aspects. Marcel Dekker Inc. New York.

Sudarmadji, S., B. Haryadi, dan Suhardi. 1997. Prosedur Analisa untuk Bahan Makanan dan Pertanian. Penerbit Liberty. Yogyakarta.

Surono, I. S, 2004. Probiotik Susu Fermentasi dan Kesehatan. YAPMMI.TRICK. Jakarta. p. 31-32

Suskovic, J, B. Kos, J. Goreta, and S. Matosic. 2001. Role of Lactic Acid Bacteria and Bifidobacteria in Synbiotic Effect. Food Technology Bitechnology 39 (3) $227-235$

Widjanarko, S.B. 1991. Fisiologi Lepas Panen. Jurusan Teknologi Hasil Pertanian. Fakultas Teknologi Pertanian. Universitas Brawijaya. Malang

Yoon, K. Y., Edward E. W. and Yong D. H. 2004. Probiotication of Tomato Juice By Lactic Acid Bacteria. Journal of Microbiology 315-318 